ISSN : 2580-3220, E-ISSN : 2580-4588

J. Mandiri., Vol. 2, No. 1, Juni 2018 (43 - 64)

(C)2018 Lembaga Kajian Demokrasi

dan Pemberdayaan Masyarakat (LKD-PM)

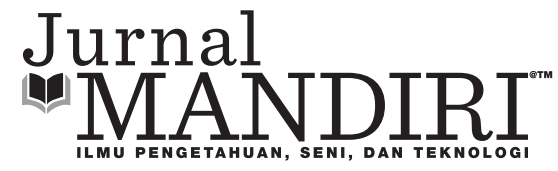

\title{
ANALISIS PENGARUH CAR, LDR, NIM, DAN BOPO TERHADAP PERTUMBUHAN LABA BANK-BANK UMUM PEMERINTAH PERIODE 2010 - 2015
}

\author{
Nurwita \\ Fakultas Ekonomi, Universitas Pamulang \\ nurwitasalma@gmail.com
}

\begin{abstract}
Abstrak
Penelitian ini bertujuan untuk mengetahui besarnya pengaruh CAR terhadap pertumbuhan laba BankBank Umum Pemerintah, pengaruh LDR terhadap pertumbuhan laba Bank-Bank umum Pemerintah, pengaruh NIM terhadap pertumbuhan laba Bank-Bank Umum Pemerintah, pengaruh BOPO terhadap pertumbuhan laba Bank-Bank Umum Pemerintah dan Pengaruh CAR, LDR, NIM, dan BOPO secara bersama-sama terhadap pertumbuhan laba Bank-Bank Umum Pemerintah.Penulis mengambil populasi keseluruhan Laporan Bank Umum Pemerintah (Bank Mandiri,BRI,BNI,dan BTN) dari tahun 20102015. Sampel penelitian ini adalah laporan keuangan tahunan menegnai CAR, LDR, NIM, BOPO, dan pertumbuhan laba tahun 2010-2015 selama enam tahun. Metode Penelitian yang digunakan adalah Deskriptif Kuantitatifberguna untuk menganalisis pengaruh antara variabel bebas dengan variabel terikat yangmenggunakan uji T dan uji F. dari hasil penelitian uji Tyaitu CARt-hitung $>$ t-tabel $(2,98197>1,98638)$ nilai signifikasi sebesar 0,0138<0,05 maka Ho1 ditolak sehingga pengaruh CAR positif signifikan terhadap pertumbuhan laba,LDR $t$-hitung $>$-tabel $(4,456693>1,98638)$ nilai signifikasi sebesar 0,0276<0,05 maka Hol ditolak sehingga pengaruh LDR positif signifikan terhadap pertumbuhan laba,NIM t-hitung $>$ ttabel $(3,104055>1,98638)$ nilai signifikasi sebesar 0,0056<0,05 maka Ho1 ditolak sehingga pengaruh NIM positif signifikan terhadap pertumbuhan laba,BOPO t-hitung $>$ t-tabel $(3,56827>1,98638)$ nilai signifikasi sebesar 0,0337 <0,05 maka Ho1 ditolak sehingga pengaruh BOPO negatif signifikan terhadap pertumbuhan laba,dan berdasarkan uji F maka F-hitung $>$ F-tabel $(11,679 .>1,98638)$ nilai signifikansi 0,0000001<0,05 maka dapat disimpulkan CAR,LDR,NIM.dan BOPO bersama-sama mempengaruhi pertumbuhan laba bank-bank umum pemerintah tahun 2010-2015.
\end{abstract}

Kata Kunci: CAR, LDR, NIM, BOPO, dan Pertumbuhan Laba

\section{PENDAHULUAN}

\section{Latar Belakang}

Pembangunan ekonomi menjadi syarat dalam menciptakan kesejahteraan suatu negara, khususnya negara Indonesia, maka banyak lembaga dan pihak yang terlibat serta andil bagian di dalamnya, tidak terkecuali lembaga perbankan. Definisi Perbankan menurut Undang-Undang No.10 Tahun 1998 adalah segala sesuatu yang menyangkut tentang bank, mencakup kelembagaan, kegiatan usaha, serta cara dan proses dalam melaksanakan kegiatan usahanya. Lem- 
baga perbankan memiliki peranan penting dalam mengatur lalu lintas keuangan secara efektif dan efisien, sehingga sistem intermediasi seperti ini, berperan dalam mobilisasi danadana masyarakat untuk diputar sebagai salah satu sumber pembiayaan utama bagi dunia usaha, baik untuk investasi maupun produksi, dalam rangka upaya pembangunan yang berkesinambungan dalam rangka mewujudkan masyarakat Indonesia yang adil dan makmur berdasarkan Pancasila dan Undang-Undang Dasar 1945. (UU Perbankan No.10 Tahun 1998)

Bank BUMN merupakan kelompok bank paling berpengaruh dalam industri perbankan Indonesia. Keempat bank BUMN yakni Bank BRI, Mandiri, BNI, dan BTN berturutturut merupakan bank terbesar nomor satu, dua, empat, dan enam dari total 118 bank di Indonesia (Kompas, 9 Mei 2016).

Per akhir tahun 2015, total aset keempat Bank BUMN tersebut mencapai Rp 2.445,47 triliun, atau 40 persen dari total aset industri perbankan nasional sebesar Rp 6.132,58 triliun. Karena berposisi sebagai market leader dengan pangsa pasar yang besar, kinerja Bank BUMN sangat mempengaruhi kinerja perbankan nasional (Kompas, 9 Mei 2016).

Faktor pendukung untuk menghasilkan laba seoptimal bisa dilihat dari rasio NIM, BOPO, LDR, dan CAR. Faktor dari Rasio Net
Interest Margin (NIM), NIM mencerminkan risiko pasar yang timbul karena adanya pergerakan variabel pasar, hal tersebut dapat mempengaruhi keuntungan yang diperoleh bank (Surat Edaran BI No. 13/24/DPNP Tanggal 25 Oktober 2011).

Rasio BOPO bertujuan untuk mengukur tingkat efisiensi dan kemampuan bank dalam melakukan kegiatan operasinya. Peningkatan besaran pada rasio ini mencerminkan kurangnya kemampuan bank dalam mengelola usahanya, begitupun juga sebaliknya. (Surat Edaran BI No. 3/30DPNP tgl 14 Desember 2001).

Salah satu ukuran untuk mengetahui likuiditas bank adalah Loan to Deposit Ratio (LDR), yaitu seberapa besar dana bank yang disalurkan kepada kreditur. Semakin tinggi LDR maka laba bank semakin meningkat dengan asumsi bank mampu menyalurkan kreditnya dengan efektif (Surat Edaran Bank Indonesia No. 3/30/ DPNP Tanggal 14 Desember 2001).

Rasio Capital Adequacy Ratio (CAR) adalah rasio yang memperlihatkan seberapa jauh seluruh aktiva bank yang mengandung risiko ikut dibiayai dari dana modal sendiri bank disamping memperoleh dana dari sumber-sumber di luar bank (Dendawijaya, 2003: 122). Artinya tersedianya CAR akan dapat menjalankan LDR dengan efektif sehingga berdampak pada Perolehan laba yang maksimal.

Tabel 1

Perkembangan Kinerja Bank Umum Nasional Indonesia Tahun 2010 - 2015 (dalam presentase)

\begin{tabular}{|c|c|c|c|c|c|c|c|}
\hline RASIO & $\begin{array}{c}\text { STANDAR } \\
\text { BI }\end{array}$ & $\begin{array}{c}\text { TAHUN } \\
\mathbf{2 0 1 0}\end{array}$ & $\begin{array}{c}\text { TAHUN } \\
\mathbf{2 0 1 1}\end{array}$ & $\begin{array}{c}\text { TAHUN } \\
\mathbf{2 0 1 2}\end{array}$ & $\begin{array}{c}\text { TAHUN } \\
\mathbf{2 0 1 3}\end{array}$ & $\begin{array}{c}\text { TAHUN } \\
\mathbf{2 0 1 4}\end{array}$ & $\begin{array}{c}\text { TAHUN } \\
\mathbf{2 0 1 5}\end{array}$ \\
\hline CAR & $8,00 \%$ & $15.76 \%$ & $15,55 \%$ & $17,43 \%$ & $18,13 \%$ & $16,64 \%$ & $24,42 \%$ \\
\hline LDR & $80 \%-110 \%$ & $73.16 \%$ & $75.86 \%$ & $83,58 \%$ & $89.70 \%$ & $84.54 \%$ & $70,66 \%$ \\
\hline NIM & $6,00 \%$ & $5.35 \%$ & $5.42 \%$ & $5.49 \%$ & $4.89 \%$ & $3.76 \%$ & $6.26 \%$ \\
\hline BOPO & $85,00 \%$ & $85.53 \%$ & $81.67 \%$ & $74,10 \%$ & $74,08 \%$ & $79.53 \%$ & $85,51 \%$ \\
\hline
\end{tabular}

Sumber diolah: Statistik Perbankan Indonesia (SPI) 2015 
Kondisi perbankan dari segi permodalan perbankan relatif baik dan stabil dimana tahun 2015 CAR berada di level $24,42 \%$ mengalami kenaikan dari pada tahun 2010-2014. Sedangkan di sisi kinerja rentabilitas yaitu dilihat dari NIM 6,26\% di tahun 2015 berada sesuai dengan standar yang ditetapkan oleh BI naik 2,50\% dibandingkan tahun 2014 yang hanya 3,76\%. Dilihat dari efisisensi kinerja perbankan yaitu nilai BOPO meningkat di level $85,51 \%$ naik dibandingkan pada tahun 2014 hanya sebesar 79,53\%. Sementara untuk profil risiko pada perbankan, risiko likuiditas tergolong relatif tinggi dimana LDR tahun 2015 turun menjadi $70,66 \%$ dan pada tahun 2014 sebesar 84,54\% dimana kondisi ini terlihat paling rendah dibandingkan tahun-tahun sebelumnya.

Tabel 2

Proyeksi Pertumbuhan Laba Perbankan di Indonesia

\begin{tabular}{|l|r|r|r|c|}
\hline \multicolumn{5}{|c|}{ Pertumbuhan Laba } \\
\hline Jenis BUKU & Laba 2014 & Laba 2015 & Nom. Growth & Growth (\%) \\
\hline BUKU 1 & 2,72 & 3,88 & 1,16 & 42,4 \\
\hline BUKU 2 & 14,94 & 20,97 & 6,03 & 40,36 \\
\hline BUKU 3 & 22,11 & 25,82 & 3,72 & 16,81 \\
\hline BUKU 4 & 68,07 & 78,43 & 10,36 & 15,22 \\
\hline Total & 107,85 & 129,11 & $\mathbf{2 1 , 2 6}$ & 19,71 \\
\hline Sumber: OJK
\end{tabular}

Berdasarkan tabel Proyeksi Pertumbuhan Laba Perbankan di Indonesia menurut buku 1,2,3,4 berada di $19,71 \%$ untukpertumbuhannya relatif naik di tahun 2015 sehingga dalam melihat permasalahan-permasalahan yang timbul dalam memaksimalkan profit tidak terlepas dari adanya faktor eksternal makro ekonomi salah satunya perekonomian yang tidak stabil, tingkat inflasi yang cukup tinggi, suku bunga acuan tinggi sehingga pasar perbankan tidak dapat mengantisipasi risiko pasar dengan baik yang juga berdampak pada rendahnya minat deposan atau investor untuk menanamkan modalnya. Selain itu risiko internal bank dihadapkan pada risiko kredit yang tinggi, sehingga memaksa pihak bank lebih berhati-hati dalam mengelola risiko portofolionya dan cenderung menempatkan dananya pada aktiva produktif yang berisiko rendah, antara lain SBI (Laporan Tahunan Bank Indonesia, 2006).

\section{Identifikasi Masalah}

Berdasarkan dengan uraian latar belakang penelitian yang dikemukakan di atas, maka penulis dapat mengidentifikasikan masalah yaitu:

1. Laba perbankan secara umum tidak mencapai target

2. CAR yang ditentukan BI tidak mampu mendongkrak laba

3. Kredit Dana Pihak Ketiga turun

4. Pencapaian target kredit kurang

5. Menurunnya tingkat kesehatan bank

6. Meningkatnya jumlah kredit bermasalah

7. Semakin meningkatnya biaya operasional perbankan

8. Rendahnya pendapatan bunga bank

\section{Batasan Masalah}

Agar permasalahan yang diteliti tidak terlalu meluas, maka penulis membatasi masalah penelitian.

1. Perbankan umum pemerintah yang terdaftar di Bursa Efek Indonesia (BEI) dan telah menyampaikan laporan keuangan per 31 Desember selama tahun 2010-2015.

2. Perbankan umum pemerintah yang secara konsisten sahamnya diperdagangkan di Bursa Efek Indonesia (BEI) selama tahun 2010-2015.

3. Perbankan umum pemerintah yang terdaftar di BEI dan diambil 4 sebagai sampel yang memiliki total aset terbesar periode tahun 2015.

4. Penelitian ini akan difokuskan hanya pada perhitungan Capital Adequacy Ratio (CAR), Loan To Deposit Ratio (LDR), Net Interest Margin (NIM), BOPO, dan pertumbuhan laba terhadap bank-bank umum pemerintah yaitu pada empat Bank yaiu Bank Mandiri, BNI, BRI, dan BTN pada laporan keuangan yang diambil adalah periode 2010-2015. 


\section{Rumusan Masalah}

Berdasarkan latar belakang penelitian, identifikasi dan batasan masalah yang telah diuraikan di atas, maka dapat diajukan rumusan masalah sebagai berikut:

1. Bagaimana pengaruh CAR terhadap pertumbuhan laba pada Bank Umum Pemerintah?

2. Bagaimana pengaruh LDR terhadap pertumbuhan laba pada Bank Umum Pemerintah?

3. Bagaimana pengaruh NIM terhadap pertumbuhan laba pada Bank Umum Pemerintah?

4. Bagaimana pengaruh BOPO terhadap pertumbuhan laba pada Bank Umum Pemerintah?

5. Bagaimana pengaruh CAR, LDR, NIM dan BOPO secara bersama-sama terhadap pertumbuhan laba pada Bank Umum Pemerintah?

\section{Tujuan Penelitian}

Tujuan penelitian ini adalah untuk:

1. Menganalisa seberapa besar pengaruh CAR terhadap pertumbuhan laba pada Bank Umum Pemerintah.

2. Menganalisa seberapa besar pengaruh LDR terhadap pertumbuhan laba pada Bank Umum Pemerintah.

3. Menganalisa seberapa besar pengaruh NIM terhadap pertumbuhan laba pada Bank Umum Pemerintah.

4. Menganalisa seberapa besar pengaruh BOPO terhadap pertumbuhan laba pada Bank Umum Pemerintah.

5. Menganalisa seberapa besar pengaruh CAR, LDR, NIM dan BOPO secara bersama-sama terhadap pertumbuhan laba pada Bank Umum Pemerintah.

\section{Manfaat Penelitian}

Penelitian ini diharapkan akan memberi manfaat kepada pihak-pihak yang terkait, diantaranya: :
1. Manfaat Teoritis

a. Hasil penelitian ini untuk penelitiadalah sebagai pengetahuan atas pemahaman terhadap kinerja perbankan yang meliputi CAR, LDR, NIM ,BOPO dan Pertumbuhan Laba

b. Hasil penelitian ini untuk Universitas khususnya Universitas Pamulang yaitu menjadikhasanahkeilmuanmanajemen keuangan yang berkaitan dengan perbankan meliputi profitabilitas, likuiditas, dan solvabilitas.

c. Hasil penelitian ini untuk para akademis, sebagai dasar untuk melakukan penelitian selanjutnya dan memberi masukan pada perkembangan kinerja bank.

2. Manfaat Praktis

a. Hasil penelitian ini untuk dunia perbankan adalah sebagai saran masukan guna menjadi bahan pertimbangan dalam melihat kinerja bank yang dilihat dari sektor modal, kredit, bunga bank, biaya operasional dan pendapatan.

b. Hasil penelitian ini untuk para pembaca adalah sebagai wahana keilmuan yang menambah khasanah ilmu keuangan perbankan.

\section{METODOLOGI PENELITIAN \\ Ruang Lingkup Penelitian \\ Tempat Penelitian}

Penelitian ini menggunakan data pada unit kerja keuangan Bank Umum Pemerintah (Bank Mandiri, BRI, BNI dan BTN), meliputi data Laba, Capital Adequacy Ratio (CAR), Loan Deposit Ratio (LDR), Net Interest Margin (NIM), BOPO. yang diperoleh dari PT. Indonesian Capital Market Elektronik Library yang bertempat di Gedung Bursa Efek Indonesia, Tower I Lt. 5, Jl. Jend. Sudirman Kav 52-53, Jakarta 12190, Telp. 52991099

\section{Objek penelitian}

Laporan keuangan untuk meneliti Rasio 
CAR, LDR, NIM, dan BOPO terhadap pertumbuhan laba pada Bank-bank umum pemerintah. Keempat bank BUMN yakni Bank BRI, Mandiri, BNI, dan BTN berturut-turut merupakan bank terbesar nomor satu, dua, empat, dan enam dari total 118 bank di Indonesia namun diambil 4 sebagai sampel yang memiliki total aset terbesar periode tahun 2015.

\section{Waktu Penelitian}

Pengambilan data pada bulan Juni sampai dengan Agustus 2016 dengan data laporan keuangan tahun 2010 sampai dengan tahun 2015.

\section{Sifat Penelitian}

Adapun sifat penelitian ini bersifat deskriptif kuantitatif. Menurut Sugiyono (2012: 8) yaitu penelitian kuantitatif adalah metode penelitian yang berlandaskan pada filsafat positivisme, digunakan untuk meneliti pada populasi atau sampel tertentu, pengumpulan data menggunakan instrumen penelitian, analisis data bersifat kuantitatif/statistik, dengan tujuan untuk menguji hipotesis yang telah ditetapkan. Menurut Sugiyono (2012: 13) penelitian deskriptif yaitu, penelitian yang dilakukan untuk mengetahui nilai variabel mandiri, baik satu variabel atau lebih (independent) tanpa membuat perbandingan, atau menghubungkan dengan variabel yang lain. Berdasarkan teori tersebut, penelitian deskriptif kuantitatif, merupakan data yang diperoleh dari sampel populasi penelitian dianalisis sesuai dengan metode statistik yang digunakan.

\section{Populasi}

Menurut (Sugiyono, 2005: 77) populasi adalah wilayah generalisasi yang terdiri atas obyek atau subyek yang mempunyai kualitas dan karakteristik tertentu yang ditetapkan oleh peneliti untuk dipelajari dan kemudian ditarik kesimpulannya. Populasi yang dimaksud di sini adalah keseluruhan Laporan Keuangan Bank Umum Pemerintah (Bank Mandiri, BRI, BNI dan BTN) dari tahun 2010 sampai dengan tahun 2015.

\section{Sampel}

Sampel merupakan bagian dari jumlah dan karakteristik yang dimiliki oleh populasi tersebut. Dengan kata lain sampel adalah perwakilan dari populasi yang digunakan untuk penelitian, yang kemudian hasilnya digeneralisasi. Adapun metode pengambilan data yang digunakan dalam penarikan sampel ini adalah sampling jenuh atau sensus. Pengertian dari sampling jenuh atau sensus menurut Sugiyono (2008: 122) adalah: "Sampling jenuh atau sensus adalah teknik peentuan sampel bila semua anggota populasi digunakan sebagai sampel" Oleh karena itu, sampel dalam penelitian ini adalah laporan keuangan Bank Umum Pemerintah (Bank Mandiri, BRI, BNI dan BTN) periode tahun 2010 - 2015, yakni berjumlah 96 data.

\section{Metode Pengumpulan dan Pengolahan Data}

Secara umum teknik atau cara pengumpulan data dalam suatu penelitian dapat dilakukan dengan 2 (dua) metode, yaitu primer dan sekunder. Artinya teknik pengambilan data disesuaikan dengan jenis dan karakteristik data. Dalam Penelitian ini menggunakan data sekunder yang diperoleh dari Laporan Keuangan Bank-bank Umum Pemerintah, bukubuku literature dan data lainnya yang menguraikan objek penelitian. Pengumpulan data sekunder berupa laporan keuangan bank umum pemerintah.

Pengolahan Data dalam penelitian ini menggunakan aplikasi Eviews versi 7.0, Bentuk data yang dimiliki terdiri dari data time series untuk tiap bank yaitu dari triwulan 1-4 pada tahun 2010-2015 sehingga tiap bank terdiri dari 6 tahun observasi berupa data triwulanan maka tiap bank memiliki 24 observasi $(\mathrm{T}=24)$ dan data cross section Jumlah observasi dari 4 bank $(\mathrm{N}=4)$ maka kedua jenis data ini akan digabungkan $\mathrm{N} \times \mathrm{T}=4 \times 24=96$ observasi. Data gabungan cross section dan time series sebanyak 
96 observasi ini selanjutnya Penyusunan Data dengan aplikasi Eviews versi 7.0

Setelah memasukan data diatas kedalam aplikasi Eviews kemudian dilakukan adalah:

1) Uji asumsi klasik seperti uji normalitas, uji multikolinearitas, uji autokorelasi, uji heterokasdisitas,

2) Uji Hipotesis seperti uji F (simultan), uji-T (parsial), koefisien determinasi (R2).

3) Uji Regresi Linier Berganda.

\section{Model Penelitian}

Model Penelitian menggambarkan pengaruh CAR, LDR, NIM, BOPO terhadap pertumbuhan laba bank umum pemerintah, maka akan terjadinya pada model penelitian pada gambar berikut:

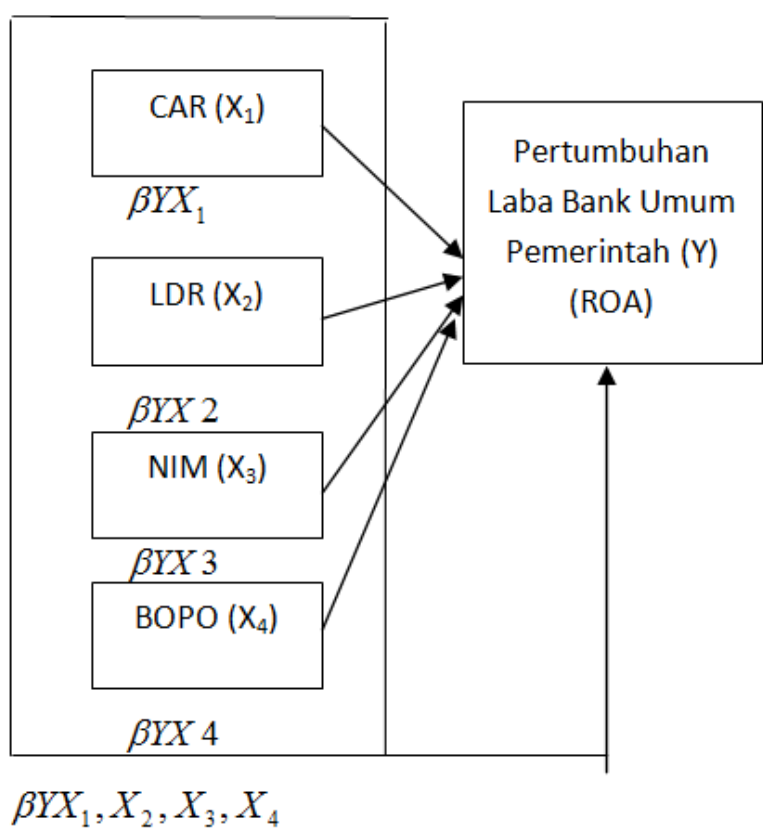

Gambar 1

Hubungan antar variabel

\section{Desain Penelitian}

Desain penelitian adalah kerangka atau rancangan untuk mengadakan suatu penelitian yang memuat prosedur dalam upaya memperoleh informasi serta mengolahnya dalam rangka memecahkan masalah (Freddy Rangkuti, 2011:16). Desain Penelitian menggambarkan serangkaian proses yang diperlukan dalam perencanaan dan pelaksanaan penelitian hingga mendapatkan hasil sebuah pembahasan dan penutup hingga kesimpulan dan saran yang diperoleh dari penelitian tentang "Analisis Pengaruh Capital Adequacy Ratio (CAR), Loan To Deposit Ratio (LDR), Net Interest Margin (NIM), Biaya Operasional Terhadap Pendapatan Operasional (BOPO) terhadap pertumbuhan laba pada Bank-Bank Umum Pemerintah Periode Tahun 2010-2015" adalah pada halaman berikut:

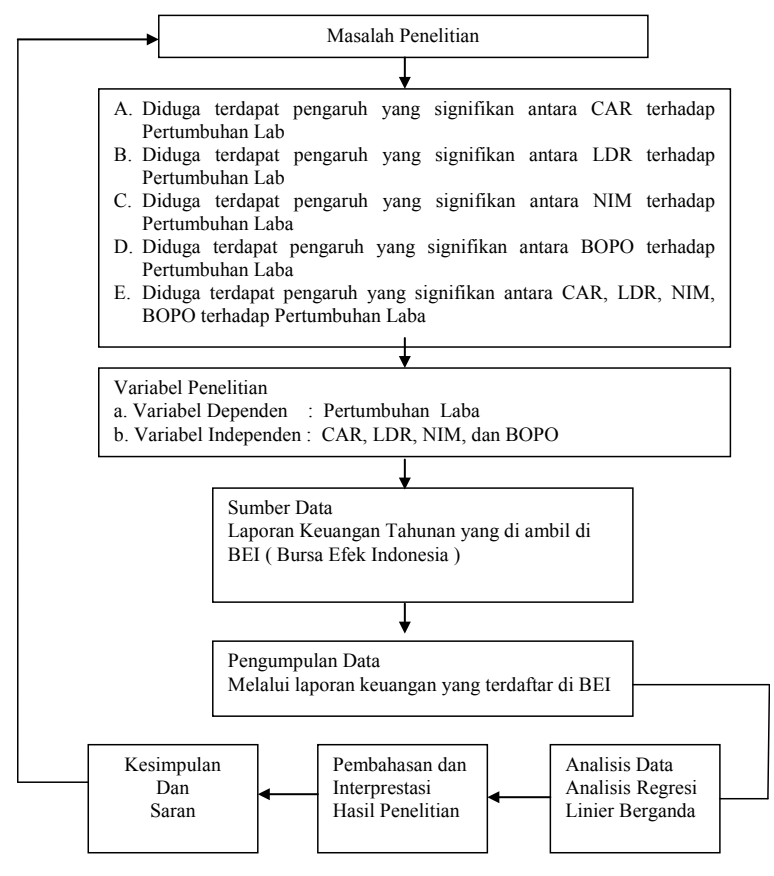

Gambar 2

Desain Penelitian

Penyajian kembali bentuk pengaruh CAR, LDR, NIM, dan BOPO terhadap pertumbuhan laba dalam bentuk persamaan regresi yang telah penulis sajikan, yaitu:

$Y=\alpha+\beta_{1} X_{1}+\beta_{2} \ln \left(X_{2}\right)+\beta_{3} X_{3}+\beta_{4} \ln \left(X_{4}\right)+\varepsilon$

Dimana $X_{1}, X_{2}, X_{3}, X_{4}$, dan $\varepsilon$ masingmasing adalah CAR, LDR, NIM, BOPO, dan error. Definisi operasional dari variabel-variabel diatas penulis sajikan pada seksi berikut. 


\section{Definisi Operasional Variabel dan Pengukuran Variabel}

Tabel 3

Kisi - Kisi Variabel Penelitian

\begin{tabular}{|c|c|c|c|}
\hline Variabel & $\begin{array}{c}\text { Operasional } \\
\text { Variabel }\end{array}$ & Parameter & Skala \\
\hline $\begin{array}{l}\text { Pertumbuhan } \\
\text { Laba } \\
\text { (Y) }\end{array}$ & $\begin{array}{l}\text { Merupakan rasio antara laba } \\
\text { periode saat ini dikurangi } \\
\text { laba periode sebelumnya } \\
\text { dibagi dengan laba periode } \\
\text { sebelumnya. Laba yang } \\
\text { digunakan adalah laba } \\
\text { sebelum pajak }\end{array}$ & $\begin{array}{l}\text { Perubahan } L a b a=\underline{L(t)-L(t-1)} \\
L(t-1)\end{array}$ & Ratio \\
\hline $\begin{array}{l}\text { Capital } \\
\text { Adequacy Ratio } \\
\text { CAR } \\
\left(X_{1}\right)\end{array}$ & $\begin{array}{l}\text { Rasio yang memperlihatkan } \\
\text { seberapa jauh seluruhaktiva } \\
\text { bank yang mengandung } \\
\text { risiko ikut dibiayai dari } \\
\text { dana modal sendiri bank, } \\
\text { disamping memperoleh } \\
\text { dana-dana dari sumber- } \\
\text { sumber di luar bank }\end{array}$ & $\mathrm{CAR}=\frac{\text { Equity Capital }}{\text { Total Loans }+ \text { Securities }} \times 100 \%$ & Ratio \\
\hline $\begin{array}{l}\text { Loan to Deposit } \\
\text { Ratio } \\
\text { LDR } \\
\left(\mathrm{X}_{2}\right)\end{array}$ & $\begin{array}{l}\text { Merupakan perbandingan } \\
\text { antara total kredit yang } \\
\text { diberikan dengan total } \\
\text { Dana Pihak Ketiga (DPK) } \\
\text { yang dapat dihimpun oleh } \\
\text { bank }\end{array}$ & $\mathrm{LDR}=\frac{\text { Total Loan }}{\text { Total Deposit }+ \text { Equity }} \times 100 \%$ & Ratio \\
\hline $\begin{array}{l}\text { Net Interest } \\
\text { Margin } \\
\text { NIM } \\
\left(X_{3}\right)\end{array}$ & $\begin{array}{l}\text { Merupakan selisih antara } \\
\text { pendapatan bunga bank } \\
\text { dengan biaya bunga bank } \\
\text { yang menjadi beban dan } \\
\text { dibagi dengan rata-rata } \\
\text { aktiva produktif yang } \\
\text { digunakan }\end{array}$ & $\mathrm{NIM}_{=}=\frac{\text { Pendapatan Bunga Bersih }}{\text { Rata }- \text { Rata Total Aset Produktif }} \times 100 \%$ & Ratio \\
\hline $\begin{array}{l}\text { BOPO } \\
\left(X_{4}\right)\end{array}$ & $\begin{array}{l}\text { Merupakan selisih antara } \\
\text { beban operasional dengan } \\
\text { pendapat operasional }\end{array}$ & $B O P O=\frac{\text { Biaya Operaional }}{\text { Pendapatan Operasional }} \times 100 \%$ & Ratio \\
\hline
\end{tabular}

\section{Metode Analisa Data}

\section{Pengujian Asumsi Klasik}

\section{a. Uji Normalitas}

Uji normalitas ini bertujuan untuk menguji apakah dalam model regresi panel variabelvariabelnya berdistribusi normal atau tidak. Model regresi yang baik adalah memiliki distribusi data normal atau mendekati normal. Tidak terpenuhinya normalitas pada umumnya disebabkan karena distribusi data yang dianalisis tidak normal, karena terdapat nilai ekstrem pada data yang diambil. Nilai ekstrem ini dapat terjadi karena adanya kesalahan dalam pengambilan sampel, bahkan karena kesalahan dalam melakukan input data atau memang karena karakteristik data tersebut sangat jauh dari rata-rata. (Suliyanto, 2011:69)

Dalam software eviews versi 7.0 yang peneliti gunakan dalam penelitian ini, normalitas data dapat diketahui dengan membandingkan statistik Jarque-Bera (JB) dengan $\chi^{2}$ chi-square table. Jika nilai Jarque-Bera (JB) $<\chi^{2}$ chi-square tabel maka nilai residual terstandarisasi dinyatakan berdistribusi normal. (Suliyanto, 2011:75). Hipotesis yang digunakan adalah:

Ho : Data berdistribusi normal

$\mathrm{Ha}$ : Data tidak berdistribusi normal

Jika hasil dari JB hitung > Chi Square tabel, maka Ho ditolak

Jika hasil dari JB hitung < Chi Square tabel, 
maka Ho diterima

$$
\mathrm{JB}=\frac{n}{6} \cdot\left(S^{2}+\frac{(K-3)^{2}}{4}\right)
$$

Keterangan:

$\mathrm{N}$ = Jumlah sample

$\mathrm{S}$ = Skewness

$\mathrm{K}=$ Kurtosis

Chi Square merupakan salah jenis uji hipotesa yang dikenal dalam statistik. Distribusi chi square dilambangkan dengan $\chi 2$. Kegunaan Uji Chi Square adalah untuk menguji hubungan ataupengaruh dua buah variabel nominal dan mengukur kuatnya hubungan antara variabel yang satu dengan variabel nominal lainnya (C $=$ Coefisien of contingency). Karakteristik ChiSquare:

1) Nilai Chi-Square selalu positif.

2) Terdapat beberapa keluarga distribusi ChiSquare, yaitu distribusi Chi-Square dengan $\mathrm{DK}=1,2,3$, dst.

3) Bentuk Distribusi Chi-Square adalah menjulur positip. Semakin besar derajat bebas, semakin mendekati distribusi normal.

4) $\mathrm{df}=\mathrm{k}-1$, dimana $\mathrm{k}$ adalah jumlah katagori. Jadi bentuk distribusi chi square tidak ditentukan banyaknya sampel, melainkan banyaknya derajat bebas.

\section{Rumus Chi Square:}

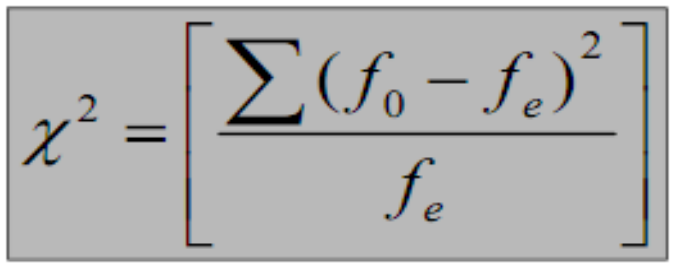

Keterangan:

$\chi^{2}=$ Nilaichi-kuadrat

$\mathrm{f}_{\mathrm{e}}=$ Frekuensi yang diharapkan

$\mathrm{f}_{\mathrm{o}}=$ Frekuensi yang diperoleh/diamati

\section{b. Uji Multikolinearitas}

Uji ini bertujuan untuk menguji apakah dalam model regresi panel ditemukan adanya korelasi antar variabel independen atau tidak. Metode untuk mendeteksi ada tidaknya masalah multikolinearitas dalam suatu model regresi juga dapat dilihat dari korelasi parsial antar variabel independen. Sebagai aturan yang kasar (rule of thumb), jika koefesien korelasi cukup tinggi diatas 0,8 maka kita duga ada multikoliniearitas dalam model. Sebaliknya jika koefisien korelasi kurang dari 0,8 maka kita duga model tidak mengandung unsur multikolinearitas (Widarjono, 2009:106).

Hipotesis yang digunakan:

Ho : residual dari model tidak ada multikolinearitas

Ha : residual dari model ada multikolinearitas

\section{c. Uji Autokorelasi}

Menurut Suliyanto (2011:125) Autokorelasi adalah adanya korelasi antara variabel itu sendiri, pada pengamatan yang berbeda waktu atau individu. Umumnya kasus autokorelasi banyak terjadi pada data time series.

Hipotesis yang dibangun dalam pengujian Autokorelasi adalah:

Ho: Tidak terdapat Autokorelasi

Ha : Terdapat Autokorelasi

Menerima atau menolak hipotesis awal dilakukan dengan membandingkan $\mathrm{x}^{2}$-hitung R-squared dan $\mathrm{x}^{2}$ tabel Chi-square pada

$\alpha=5 \%$. jika $x^{2}$-hitung R-squared $<\mathrm{x}^{2}$ tabel Chi-square maka menerima hipotesis awal, artinya tidak terdapat autokorelasi.

\section{d. Uji Heteroskedastisitas}

Heteroskedastisitas berarti ada varian variabel pada model regresi yang tidak sama (konstan). Sebaliknya jika varian variabel pada model regresimemilikinilaiyang sama(konstan) maka disebut dengan homokedastisitas. Masalah heteroskedastisitas sering terjadi pada penelitian yang menggunakan data cross section.

Hipotesis yang digunakan: 
Ho : residual dari model tidak ada Heteroskedastisitas

Ha: residual dari model ada Heteroskedastisitas

Adapun beberapa contoh penyebab perubahan nilai varian yang berpengaruh pada homoskedastisitas residualnya adalah sebagai berikut:

1) Adanya pengaruh dari kurva pengalaman (learning curve)

Dengan semakin maningkatnya pengalaman maka semakin menurun tingkat kesalahannya. Akibatnya, nilai varian makin lama semakin menurun.

2) Adanya peningkatan perekonomian

Dengan semakin meningkatnya perekonomian maka semakin beragam tingkat pendapatan sehingga alternatif pengeluaran juga akan semakin besar. Hal ini akan meningkatkan varian.

3) Adanya peningkatan teknik pengambilan data

Jika teknik pengambilan data semakin membaik, nilai varian cenderung mengecil.

Misalnya bank yang menggunakan peralatan Electronic Data Processing (EDP) akan membuat kesalahan yang relatif kecil dalam laporan, dibandingkan dengan bank yang tidak mempunyai peralatan tersebut.

\section{Uji Hipotesis}

\section{a. Uji F (Simultan)}

Uji F simultan ialah untuk menguji pengaruh variabel tak bebas secara keseluruhan .Uji F-statistik biasa nya berupa:

Ho: Variabel bebas tidak mempengaruhi variabel tak bebas

Ha: Variabel bebas mempengaruhi variabel tak bebas

Jika dalam pengujian kita menerima Ho maka dapat kita simpulkan bahwa tidak terdapat hubungan yang linier antara dependen variabel dengan independen variabel.
Hipotesa nya adalah sebagai berikut:

Ho: diterima bila $\|$ F-statistik $\|<\|$ F-tabel $\|$

Ho: ditolak bila ||F-statistik $\|>\|$ F-tabel $\|$

Dengan rumus uji F hitung:

$$
F h=\frac{R^{2} / k}{\left(1-R^{2}\right) /(n-k-1)}
$$

Keterangan:

$\mathrm{R}^{2}=$ Koefisien Regresi

$\mathrm{n}=$ Jumlah Sampel

$\mathrm{k}=$ Jumlah variabel Independen

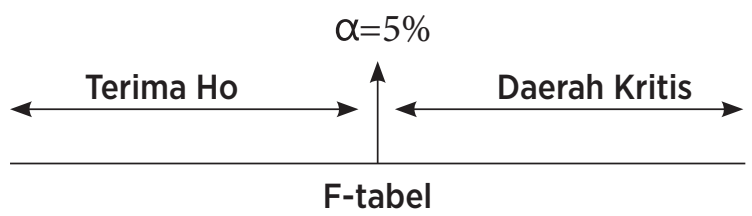

Gambar 3

Analisa Uji F

Dari hasil output analisa uji F maka yang akan di hasilkan jika Ho ditolak maka berada disebelah kanan semua variabel bebas akan mempengaruhi variabel terikat.

\section{b. Uji T parsial}

Uji T Statitistik digunakan untuk menguji pengaruh variael variabel bebas terhadap variabel tak bebas secara parsial uji t-statistik biasanya berupa penguji hipotesa:

Dengan menguji dua arah dalam tingkat signifikansi $\alpha=5 \%$ dan $d f=n-k-1 \quad(n=j u m l a h$ observasi, $\mathrm{k}=\mathrm{jumlah}$ variabel bebas ) maka hasil pengujian akan menunjukkan :

Ho: diterima bila $\|$ t-statistik $\|<\|$ t-tabel $\|$

Ho: ditolak bila||t-statistik $\|>\| t$-tabel $\mid$

Rumus T hitung

$$
t=\frac{r \sqrt{n-2}}{\sqrt{1-r^{2}}}
$$


Keterangan :

$\mathrm{r}=$ Koefisien korelasi

$\mathrm{n}=$ Jumlah responden $(\mathrm{n}-2=\mathrm{dk}$, derajat kebebasan)

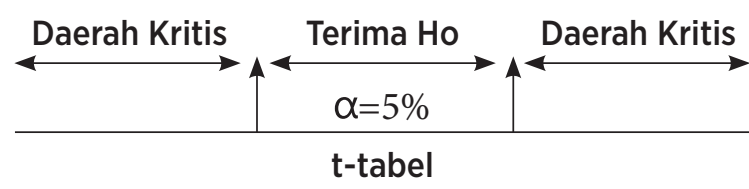

Gambar 4

Analisa uji

Dari hasil Analisa uji T maka bila hipotesis Ho diterima akan berada di daerah tengah sedangkan jika Ho tolak maka akan tersedia di sebelah kanan dan kiri.

\section{c. Koefisien determinasi $\left(\mathbf{R}^{2}\right)$}

Digunakan untuk mengukur seberapa besar variabel-variabel bebas dapat menjelaskan variabel terikat. Koefisien ini menunjukan seberapa besar variasi total pada variabel terikat yang dapat dijelaskan oleh variabel bebasnya dalam model regresi tersebut. Nilai dari koefisien determinasi ialah antara 0 hingga 1 . Nilai $\mathrm{R}^{2}$ yang mendekati 1 menunjukan bahwa variabel dalam model tersebut dapat mewakili permasalahan yang diteliti, karena dapat menjelaskan variasi yang terjadi pada variabel dependennya. Nilai $\mathrm{R}^{2}$ sama dengan atau mendekati 0 ( nol) menunjukan variabel dalam model yang dibentuk tidak dapat menjelaskan variasi dalam variabel terikat. Nilai koefisien determinasi akan cenderung semakin besar bila jumlah variabel bebas bila jumlah variabel bebas dan jumlah data yang diobservasi semakin banyak. Oleh Karena itu maka digunakan ukuran Adjusted $\mathrm{R}^{2}\left(\mathrm{R}^{2}\right)$, untuk menghilangkan bias akibat adanya penambahan jumlah variabel bebas dan jumlah data yang diobservasi.

Analisis melalui program Eviews dapat diestimasi nilai Adjusted $\mathrm{R}^{2}$ menandakan bahwa pertumbuhan laba (Y) mampu dijelaskan secara serentak oleh variabel CAR (X1), LDR (X2), NIM (X3), dan BOPO (X4) sebesar nilai Adjusted $\mathrm{R}^{2}$ tsb dan sisanya dari 1- nilai Adjusted
$\mathrm{R}^{2}$ dijelaskan faktor faktor lain yang tidak masuk dalam model menggunakan rumus sebagai berikut:

$$
K D=r^{2} \times 100 \%
$$

\section{Keterangan: \\ $\mathrm{KD}=$ Koefisien Determinasi \\ $\mathrm{R}^{2}=$ Koefisien Korelasi}

Koefisien Determinasi merupakan kuadrat dari koefisien korelasi parsial untuk mengetahui sampai seberapa jauh variabel independen dapat menjelaskan variabel dependen. Koefisien korelasi merupakan salah satu teknik statistika yang digunakan untuk mencari 2 variabel atau lebih yang sifatnya kuantitatif (Sugiyono, 2014: 250).

Tabel 4 Interprestasi Koefesien Korelasi

\begin{tabular}{|l|l|}
\hline Interval Koefisien & \multicolumn{1}{|c|}{ Tingkat Hubungan } \\
\hline $0,00-0,199$ & Sangat Rendah \\
$0,20-0,399$ & Rendah \\
$0,40-0,599$ & Sedang \\
$0,60-0,799$ & Kuat \\
$0,80-1,000$ & Sangat Kuat \\
\hline
\end{tabular}

Sumber : Sugiyono,2014:250

\section{d. Analisis regresi linear berganda.}

Model analisis ini merupakan analisis yang bersifat kuantitatif yang digunakan untuk mengetahui sejauh mana besarnya pengaruh antara variabel bebas dengan variabel terikat. Di dalam penelitian ini peneliti menggunakan uji regresi liner berganda yaitu pengujian yang dilakukan untuk melihat pengaruh dari dua variabel bebas terhadap variabel terikatnya namun masih menunjukkan hubungan yang linear. Model regresi data panel secara umum adalah sebagai berikut:

$$
\hat{\mathbf{Y}}=\mathbf{a}+\mathbf{b}_{1} \mathrm{X}_{1}+\mathbf{b}_{2} \ln \left(\mathrm{X}_{2}\right)+\mathbf{b}_{3} \mathrm{X}_{3}+\mathbf{b}_{4} \ln \left(\mathrm{X}_{4}\right)+\varepsilon
$$

Dari persamaan regresi data panel tersebut, maka model persamaan regresi data panel yang 
digunakan pada penelitian ini adalah :

$\mathrm{PL}=\mathrm{a}+\mathrm{b}_{1} \mathrm{CAR}+\mathrm{b}_{2} \ln (\mathrm{LDR})+\mathrm{b}_{3} \ln$ $(\mathrm{NIM})+\mathrm{b}_{3} \mathrm{BOPO}+\varepsilon$

Keterangan :

$\hat{\mathrm{Y}}=$ variabel dependen $(\mathrm{HS})$

$\mathrm{X}_{1}=$ variabel independen pertama $(\mathrm{CAR})$

$\mathrm{X}_{2}=$ variabel independen kedua $(\mathrm{LDR})$

$\mathrm{X}_{3}=$ variabel independen ketiga $(\mathrm{NIM})$

$\mathrm{X}_{4}=$ variabel independen keempat (BOPO)

$\mathrm{a}=$ koefisien konstanta

$\mathrm{b}_{1}=$ koefisien regresi

$\varepsilon=$ Error term

\section{HASIL PENELITIAN DAN PEMBAHASAN}

\section{Hasil Penelitian}

\section{Analisis Deskriptif Variabel}

Variabel independen dalam penelitian ini yakni: Capital Adequacy Ratio (CAR), Loan to Deposit Ratio (LDR), Net Interest Margin (NIM) dan Biaya Operasional terhadap Pendapatan Operasional (BOPO). Adapun variabel dependennya adalah Pertumbuhan laba yang diambil selama periode 2010-2015. Penjelasan lebih lanjut sebagai berikut:

a. Gambaran Capital Adequacy Ratio (CAR) Pada Perbankan Perbankan Yang Listing di Bursa Efek Indonesia (BEI) tahun 2010-2015

Capital Adequacy Ratio (CAR) merupakan rasio yang digunakan untuk menilai keamanan dan kesehatan bank dari sisi modal atau untuk mengukur kecukupan modal yang dimiliki bank untuk menunjang aktiva yang mengandung risiko. Rasio Capital Adequacy Ratio (CAR) dihitung dari modal dengan aktiva tertimbang menurut resiko. Capital Adequacy Ratio (CAR) merupakan indikator terhadap kemampuan bank untuk menutupi penurunan aktivanya sebagai akibat dari kerugian-kerugian bank yang disebabkan oleh aktiva yang beresiko. Untuk mengetahui besarnya CAR pada perusahaan perbankan yang dijadikan sampel penelitian pada periode 2010-2015 dapat dilihat pada tabel berikut:
Tabel 5

Capital Adequacy Ratio (CAR) Pada Perbankan Yang Listing di Bursa Efek Indonesia tahun 2010-2015 (Dalam persen)

\begin{tabular}{|c|c|c|c|c|c|c|}
\multirow{2}{*}{ BANK } & \multicolumn{6}{|c|}{ TAHUN } \\
\cline { 2 - 7 } & $\mathbf{2 0 1 0}$ & $\mathbf{2 0 1 1}$ & $\mathbf{2 0 1 2}$ & $\mathbf{2 0 1 3}$ & $\mathbf{2 0 1 4}$ & $\mathbf{2 0 1 5}$ \\
\hline MANDIRI & 15.43 & 13.36 & 15.34 & 15.48 & 14.93 & 16.60 \\
\hline BRI & 13.20 & 16.95 & 14.96 & 13.96 & 13.20 & 13.18 \\
\hline BNI & 13.78 & 13.5 & 13.8 & 18.6 & 17.6 & 16.7 \\
\hline BTN & 21.49 & 16.14 & 21.54 & 16.74 & 15.03 & 17.69 \\
\hline
\end{tabular}

sumber: www.idx.co.id

Berdasarkan tabel 5 di atas dapat dilihat bahwa CAR pada perbankan yang listing di Bursa Efek Indonesia periode 2010-2015 sangat berfluktuasi. Angka tertinggi CAR sebesar 21,54\% pada Bank BTN di tahun 2012, sedangkan angka terendah CAR sebesar 13,18\% pada Bank Rakyat Indonesia di tahun 2015. Meskipun CAR pada perbankan berfluktuasi tetapi perbankan telah memenuhi standar angka CAR yang ditetapkan Bank Indonesia yaitu lebih dari $8 \%$.

\section{b. Loan to Deposit Ratio (LDR) Pada Perbankan Yang Listing di Bursa Efek Indonesia tahun 2010-2015}

Loan to Deposit Ratio (LDR) adalah perbandingan antara total Pertumbuhan Laba yang diberikan dengan total Dana Pihak ketiga (DPK) yang dapat dihimpun oleh bank. Loan to Deposit Ratio (LDR) akan menunjukan tingkat kemampuan bank dalam menyalurkan Dana Pihak Ketiga yang dihimpun oleh bank yang bersangkutan. Maksimal Loan to Deposit Ratio (LDR) yang diperkenankan oleh bank Indonesia adalah sebesar $110 \%$. 
Tabel 6 Loan to Deposit Ratio (LDR)

(Dalam persen)

\begin{tabular}{|c|c|c|c|c|c|c|}
\hline \multirow{2}{*}{ BANK } & \multicolumn{5}{|c|}{ TAHUN } \\
\cline { 2 - 7 } & $\mathbf{2 0 1 0}$ & $\mathbf{2 0 1 1}$ & $\mathbf{2 0 1 2}$ & $\mathbf{2 0 1 3}$ & $\mathbf{2 0 1 4}$ & $\mathbf{2 0 1 5}$ \\
\hline MANDIRI & 59.15 & 65.44 & 71.65 & 77.66 & 82.97 & 82.97 \\
\hline BRI & 75.17 & 79.85 & 76.20 & 75.17 & 80.88 & 79.93 \\
\hline BNI & $64 . .06$ & 68,60 & 64,10 & 70,20 & 70,40 & 77,50 \\
\hline BTN & 101.29 & 87,84 & 95,11 & 88,04 & 94,41 & 95,04 \\
\hline
\end{tabular}

sumber: www.idx.co.id

Berdasarkan tabel diatas, dapat disimpulkan bahwa sejak tahun 2010-2015 Loan to Deposit Ratio (LDR) tertinggi ada beberapa bank yang menduduki tingkat teratas, namun Loan to Deposit Ratio (LDR) tertinggi terjadi pada tahun 2010 pada Bank BTN yaitu sebesar 101.29\%. Hal ini dikarenakan Loan to Deposit Ratio (LDR) Bank diimbangi oleh permodalan yang kuat dengan rasio KPMM konsolidasian sebesar $18,9 \%$ dibandingkan $17,6 \%$ pada tahun 2011, mencerminkan likuiditas yang baik untuk melanjutkan pertumbuhan laba. Sedangkan Loan to Deposit Ratio (LDR) terendah sejak tahun 2010-2015 diduduki oleh bank BNI. Pertumbuhan dana pihak ketiga yang lebih tinggi dibandingkan Pertumbuhan Laba menyebabkan rasio Pertumbuhan Laba terhadap Dana Pihak Ketiga (LDR) mengalami penurunan.

\section{c. Gambaran Net Interest Margin (NIM) Pada Perbankan Yang Listing di Bursa Efek Indonesia (BEI) tahun 2010- 2015}

Net Interest Margin (NIM) merupakan rasio yang digunakan untuk mengukur kemampuan manajemen bank dalam mengelola aktiva produktifnya untuk menghasilkan pendapatan bunga bersih. Net Interest Margin (NIM) diukur dari perbandingan antara pendapatan bunga bersih terhadap aktiva produktif. Pendapatan bunga bersih diperoleh dari pendapatann bunga dikurangi beban bunga. Aktiva produktif yang diperhitungkan adalah aktiva produktif yang menghasilkan bunga seperti penempatan pada bank lain, surat berharga, penyertaan, dan Pertumbuhan Laba yang diberikan. Untuk mengetahui besarnya NIM pada perusahaan perbankan yang dijadikan sampel penelitian pada periode 2010-2015 dapat dilihat pada tabel pada halaman berikut:

Tabel 7 Net Interest Margin (NIM) Pada

Perbankan Yang Listing di Bursa Efek Indonesia tahun 2010-2015

(Dalam persen)

\begin{tabular}{c|c|c|c|c|c|c|}
\multirow{2}{*}{ BANK } & \multicolumn{6}{|c|}{ TAHUN } \\
\cline { 2 - 7 } & $\mathbf{2 0 1 0}$ & $\mathbf{2 0 1 1}$ & $\mathbf{2 0 1 2}$ & $\mathbf{2 0 1 3}$ & $\mathbf{2 0 1 4}$ & $\mathbf{2 0 1 5}$ \\
\hline MANDIRI & 5.19 & 5.39 & 5.29 & 5.58 & 5.68 & 5.94 \\
\hline BRI & 10.77 & 8.42 & 9.58 & 10.77 & 9.14 & 10.18 \\
\hline BNI & 6.01 & 5.78 & 6.03 & 5.93 & 6.11 & 6.20 \\
\hline BTN & 4.60 & 5.99 & 5.76 & 5.83 & 5.44 & 4.47 \\
\hline
\end{tabular}

sumber: www.idx.co.id

Berdasarkan tabel 7 di atas dapat dilihat bahwa NIM pada perbankan yang listing di Bursa Efek Indonesia periode 2010-2015 sangat berfluktuasi. Angka tertinggi NIM sebesar $10.77 \%$ pada Bank Rakyat Indonesia di tahun 2013 dan 2010, sedangkan angka terendah NIM sebesar $4,47 \%$ pada Bank BTN di tahun 2015. Meskipun NIM pada perbankan berfluktuasi tetapi perbankan telah memenuhi standar angka NIM yang ditetapkan Bank Indonesia yaitu lebih dari $6 \%$.

d. Gambaran Operating Expense to Operating Income/Biaya Operasional terhadap Pendapatan Operasional (BOPO) Pada Perbankan Yang Listing di Bursa Efek Indonesia (BEI) tahun 2010-2015 
Biaya Operasional terhadap Pendapatan Operasional (BOPO) merupakan rasio yang digunakan untuk mengukur tingkat efisiensi dan kemampuan bank dalam melakukan kegiatan operasinya dengan standar BI adalah $85 \%$ Untuk mengetahui besarnya BOPO pada perusahaan perbankan yang dijadikan sampel penelitian pada periode 2010-2015 dapat dilihat pada tabel pada halaman berikut

Tabel 8 Biaya Operasional terhadap Pendapatan Operasional (BOPO) Pada Perbankan Yang Listing di Bursa Efek Indonesia tahun 2010-2015

(Dalam persen)

\begin{tabular}{|c|c|c|c|c|c|c|}
\multirow{2}{*}{ BANK } & \multicolumn{5}{|c|}{ TAHUN } \\
\cline { 2 - 7 } & $\mathbf{2 0 1 0}$ & $\mathbf{2 0 1 1}$ & $\mathbf{2 0 1 2}$ & $\mathbf{2 0 1 3}$ & $\mathbf{2 0 1 4}$ & $\mathbf{2 0 1 5}$ \\
\hline MANDIRI & 70.72 & 65.63 & 67.22 & 63.93 & 62.41 & 64.98 \\
\hline BRI & 70.86 & 77.66 & 66.69 & 59.93 & 61.00 & 65.37 \\
\hline BNI & 84.86 & 75.99 & 72.58 & 70.99 & 67.12 & 69.78 \\
\hline BTN & 88.29 & 83.28 & 81.75 & 80.74 & 82.19 & 89.19 \\
\hline
\end{tabular}

sumber: www.idx.co.id

\section{e. Pertumbuhan laba Pada Perbankan Perbankan Yang Listing di Bursa Efek Indonesia (BEI) tahun 2010- 2015}

Rasio ini digunakan untuk mengukur kemampuan manajemen bank dalam memperoleh keuntungan secara keseluruhan. Semakin besar Pertumbuhan laba suatu bank semakin besar pula tingkat keuntungan yang dicapai bank tersebut dan semakin baik pula posisi bank tersebut dari sisi penggunaan aset. Menurut surat edaran Bank Indonesia tahun 2004 Pertumbuhan laba yang baik nilainya lebih dari 1,25\%.
Tabel 9 Pertumbuhan laba

(Dalam persen)

\begin{tabular}{c|c|c|c|c|c|c|}
\multirow{2}{*}{ BANK } & \multicolumn{7}{|c|}{ TAHUN } \\
\cline { 2 - 7 } & $\mathbf{2 0 1 0}$ & $\mathbf{2 0 1 1}$ & $\mathbf{2 0 1 2}$ & $\mathbf{2 0 1 3}$ & $\mathbf{2 0 1 4}$ & $\mathbf{2 0 1 5}$ \\
\hline MANDIRI & 3.13 & 2,5 & 3 & 3,4 & 3,4 & 3,5 \\
\hline BRI & 4.64 & 4,18 & 3,73 & 4,64 & 4,93 & 5,15 \\
\hline BNI & 1.72 & 1,1 & 1,7 & 2,5 & 2,9 & 2,9 \\
\hline BTN & 1.80 & 1,75 & 1,78 & 1,76 & 2,02 & 1,96 \\
\hline
\end{tabular}

Berdasarkan tabel di atas, dapat disimpulkan bahwa sejak tahun 2010-2015 Pertumbuhan laba tertinggi dihasilkan oleh bank BRI yaitu sebesar 5,15\%, 4,93\%, 4,64\%, 3,73\%, 4,18\%, 4.64\% sehingga pada tahun 2015 BRI merupakan bank terbaik di Indonesia. Pada tahun 2011 hampir semua bank rata-rata mengalami penurunan Pertumbuhan laba, hal ini disebabkan oleh suatu masalah yang pernah bertahun-tahun dialami pasca krisis.

\section{Uji Asumsi Klasik}

\section{a. Uji Normalitas}

Uji normalitas dimaksudkan untuk menguji apakah nilai residual yang telah terstandarisasi pada model regresi berdistribusi normal atau tidak. Nilai residual dikatakan berdistribusi normal jika nilai residual terstandarisasi tersebut sebagian besar mendekati nilai rata-ratanya (Suliyanto, 2011: 69). Hipotesis yang digunakan: Ho : residual dari model berdistribusi normal

Ha : residual dari model tidak berdistribusi normal

Uji ini dilakukan dengan membandingkan statistik Jarque- Bera (JB) dengan $\chi^{2}$ tabel Chi-Square. Jika nilai Jarque-Bera (JB) $<\chi^{2}$ tabel Chi-Square maka dengan random effect method diketahui bahwa nilai residual terstandarisasi dinyatakan berdistribusi normal. (Suliyanto,2011:75) maka hipotesis yang digunakan adalah Ho diterima. 


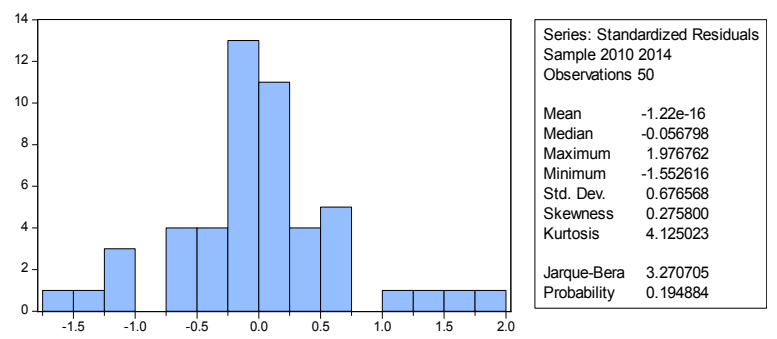

Gambar 5

Hasil Uji Normalitas

Pada hasil grafik histogram pertumbuhan laba diatas menunjukan nilai Jarque-Bera sebesar 3.270705 pada $\alpha=5 \%$ sedangkan nilai $\chi^{2}$ tabel Chi-square pada $n$ adalah obyek penelitian $(\mathrm{n}=96) \mathrm{df}=(5 \%$ :n1) $=(0,05 ; 95)=118,75$ (dilihat dari tabel Chi-square)

Analisis output yang di hasilkan dari data pengolahan uji normalitas dilihat bahwa nilai Jarque-Bera (JB) (3.270705) $<$ nilai $\chi^{2}$ tabel Chi-Square (118.75), maka hipotesis yang digunakan di uji normalitas adalah Ho diterima nilai residual terstandarisasi berdistribusi normal. Selain itu bisa diketahui juga dari tingkat probability sebesar 0,194884>0.05 ( $\mathrm{p}>5 \%$ ) maka dapat disimpulkan bahwa residual berdistribusi normal

\section{b. Uji Multikoliniearitas}

Multikoliniearitas adalah kondisi adanya hubungan erat antara variabel-variabel independen di dalam suatu model regresi. Adanya multikoliniearitas masih menghasilkan estimator BLUE (Best, Linear, Unbiased, dan Estimator), tetapi menyebabkan suatu model mempunyai varian yang besar (Widarjono, 2011:104). Dalam penelitian ini metode yang dipakai untuk mendeteksi ada tidaknya masalah multikolinearitas dalam suatu model regresi adalah dengan melihat dari korelasi parsial antar variabel independen. Sebagai aturan yang kasar (rule of thumb), jika koefesien korelasi cukup tinggi diatas 0,8 maka kita duga ada multikoliniearitas dalam model. Sebaliknya jika koefisien korelasi kurang dari 0,8 maka kita duga model tidak mengandung unsur multikolinearitas (Widarjono, 2011:106).

Hipotesis yang digunakan:

Ho : residual dari model tidak ada multikolinearitas

Ha : residual dari model ada multikolinearitas

Tabel 9

Uji Multikolinearitas

\begin{tabular}{|l|l|l|l|l|} 
& CAR & NIM & LDR & BOPO \\
\hline CAR & 1.000000 & 0.457237 & 0.281509 & -0.152975 \\
\hline NIM & 0.457237 & 1.000000 & 0.460942 & -0.105809 \\
\hline LDR & 0.281509 & 0.460942 & 1.000000 & -0.179653 \\
\hline BOPO & -0.152975 & -0.105809 & -0.179653 & 1.000000 \\
\hline
\end{tabular}

Sumber: Data diolah Eviews7

Berdasarkan matrik korelasi diatas terlihat bahwa hubungan antara variabel independennya semuanya dibawah 0,8 maka Ho di terima sehingga disimpulkan bahwa data yang digunakan dalam penelitian ini terbebas dari masalah multikolinieritas.

\section{c. Autokorelasi}

Uji autokorelasi bertujuan untuk mengetahui apakah ada korelasi antara anggota serangkaian data observasi yang diuraikan menurut waktu (time series) dan ruang (cross section) (Suliyanto, 2001: 125)

Hipotesis yang dibangun dalam pengujian Autokorelasi adalah:

Ho: Tidak terdapat Autokorelasi

Ha : Terdapat Autokorelasi

Menerima atau menolak hipotesis awal dilakukan dengan membandingkan $\mathrm{x}^{2}$-hitung $R$-squared dan $\mathrm{x}^{2}$ tabel Chi-square pada

$\alpha=5 \%$. jika $\mathrm{x}^{2}$-hitung $R$-squared $<\mathrm{x}^{2}$ tabel Chi-square maka menerima hipotesis awal, artinya tidak terdapat autokorelasi. 
Tabel 10

Uji Autokorelasi

\begin{tabular}{|l|l|l|l|}
\hline R-squared & 0.890078 & $\begin{array}{l}\text { Mean } \\
\text { dependent var }\end{array}$ & 2.423000 \\
\hline $\begin{array}{l}\text { Adjusted } \\
\text { R-squared }\end{array}$ & 0.887763 & $\begin{array}{l}\text { S.D. dependent } \\
\text { var }\end{array}$ & 0.578963 \\
\hline $\begin{array}{l}\text { S.E. of } \\
\text { regression }\end{array}$ & 0.398954 & $\begin{array}{l}\text { Sum squared } \\
\text { resid }\end{array}$ & 45.35257 \\
\hline F-statistic & 11.67875 & $\begin{array}{l}\text { Durbin-Watson } \\
\text { stat }\end{array}$ & 0.957847 \\
\hline Prob(F-statistic) & 0.000000 & & \\
\hline
\end{tabular}

Sumber: Data diolah Eviews 7

Dari output tabel uji autokorelasi terlihat bahwa $\mathrm{R}^{2}$ sebesar 0.8901

Dan jumlah pengamatan sebanyak 96. $(\mathrm{n}=96)$

$\mathrm{x}^{2}$-hitung $=(\mathrm{n}-1) \times \mathrm{R}^{2}=(95) \times \mathrm{R}^{2}=$ $(95 \mathrm{x} 0,8901)=84,5595$

Sedangkan nilai $\mathrm{x}^{2}$ tabel Chi-square dengan df: (0,05:95) diperoleh 118,75 Karena nilai $\mathrm{x}^{2}$ hitung $<\mathrm{x}^{2}$ tabel Chi-Square $(84,5595<118,75)$, maka Ho diterima sehingga model persamaan regresi tidak mengandung masalah autokorelasi.

\section{d. Uji Heteroskedastisitas}

Dalam mendeteksi ada tidaknya masalah heteroskedastisitas dapat dilakukan dengan uji park deteksi masalah heteroskedastisitas Varian yang tidak konstan atau masalah heteroskedastisitas muncul karena residual ini tergantung dari variabel independennya yang ada didalam model.

Hipotesis yang digunakan:

Ho : residual dari model tidak ada Heteroskedastisitas dan nilai probabilitas $>0.05$

$\mathrm{Ha}$ : residual dari model ada Heteroskedastisitas dan nilai probabilitas $<0.05$

Tabel 11

Uji Park

Dependent Variable: Pertumbuhan Laba

Method: Panel Least Squares

Date: 09/14/16 Time: 19:26

Sample: 20102015

Periods included: 24

Cross-sections included: 4
Total panel (balanced) observations: 96

\begin{tabular}{lllll}
\hline \hline Variable & Coefficient & Std. Error & t-Statistic & Prob. \\
\hline C & -9.084122 & 4.997174 & -1.817852 & 0.0777 \\
CAR & 0.002660 & 0.001005 & 2.647728 & 0.1121 \\
NIM & 0.078582 & 0.026647 & 2.948964 & 0.0756 \\
LOG(LDR) & 0.221711 & 0.090993 & 2.592040 & 0.0983 \\
LOG(BOPO) & -0.008805 & 0.007925 & -0.950520 & 0.5119 \\
Sumber: Data diolah Eviews 7 & & &
\end{tabular}

Berdasarkan tabel uji park dapat disimpulkan bahwa nilai probabilitas sebesar (0,1121), (0,0756), (0,0983), dan (0,5119) lebih besar dari 0,05 maka Ho diterima dapat dipastikan model tidak mengandung gejala heteroskedastisitas atau dikatakan tidak terjadi heteroskedastisitas.

\section{Uji Hipotesis}

\section{a. Uji F (simultan)}

Dilakukan untuk menguji apakah setiap variabel bebas (independent variabel) secara keseluruhan atau bersama-sama memiliki pengaruh yang signifikan terhadap variabel terikat (dependent variabel). Dalam melakukan pengujian koefisien regresi secara bersamasama digunakan uji yang dikenal dengan sebutan uji F (Nahcrowi, 2006: 17)

Adapun dasar pengambilan keputusannya menggunakan angka probabilitas signifikansi, yaitu:

1). Ho: Probabilitas signifikansi $>0.005$ dan F-hitung $<$ F-tabel pengaruh tidak signifikan.

2). Ha: Probabilitas signifikansi $<0.005$ dan F-hitung $>$ F-tabel pengaruh signifikan.

Tabel 12

Uji F (simultan)

\begin{tabular}{|l|l|l|l|}
\hline R-squared & 0.890078 & $\begin{array}{l}\text { Mean dependent } \\
\text { var }\end{array}$ & 2.423000 \\
\hline $\begin{array}{l}\text { Adjusted } \\
\text { R-squared }\end{array}$ & 0.887763 & $\begin{array}{l}\text { S.D. dependent } \\
\text { var }\end{array}$ & 0.578963 \\
\hline $\begin{array}{l}\text { S.E. of } \\
\text { regression }\end{array}$ & 0.398954 & $\begin{array}{l}\text { Sum squared } \\
\text { resid }\end{array}$ & 45.35257 \\
\hline F-statistic & 11.67875 & $\begin{array}{l}\text { Durbin-Watson } \\
\text { stat }\end{array}$ & 0.957847 \\
\hline Prob(F-statistic) & 0.000001 & & \\
\hline
\end{tabular}

Sumber: Data diolah eviews 7 
Hasil yang diperoleh dari model regresi diatas, didapat F- hitung sebesar 11,679 pada $\alpha$ $=5 \%$ menggunakan uji dua sisi (two tail test), sementara nilai F-tabel adalah:

$$
\begin{aligned}
& \text { F-tabel }=\{\alpha ; \mathrm{df}=(\mathrm{n}-\mathrm{k}-1)\} \\
& =5 \%: \mathrm{df}=(96-4-1) \\
& =0,05 ; 91 \\
& =1,98638
\end{aligned}
$$

Berdasarkan Hasil perhitungan dapat diperoleh F-hitung $>$ F-tabel $(11.679>1.98638)$. Dengan nilai probabilitas F-statistik 0,000001 yang lebih kecil dari tingkat signifikan (5\%) maka Ho ditolak dan Ha diterima. Dengan demikian, dapat disimpulkan bahwa variabel independen (CAR, NIM, LDR, BOPO) secara bersama-sama berpengaruh positif dan signifikan terhadap pertumbuhan laba pada 4 bank umum pemerintah dengan pertumbuhan laba terbesar di Indonesia selama periode 20102015.

\section{b. Uji t (Parsial)}

Menurut Ghozali (2011: 98) uji statistik $\mathrm{t}$ pada dasarnya menunjukkan seberapa jauh pengaruh satu variabel penjelas atau variabel independen secara individual dalam menerangkan variasi variabel dependen.

Uji t dilakukan dengan menggunakan uji dua sisi (two tail test), dengan $\alpha=5 \%$, maka diperoleh $\mathrm{t}$-tabel sebagai berikut:

t-tabel $=\{\alpha ; \mathrm{df}=(\mathrm{n}-\mathrm{k}-1)\}=5 \%: \mathrm{df}=(96-$ $4-1)=0,05 ; 91=1,98638$

Hipotesis yang digunakan:

Ho: diterima bila $\| \mathrm{t}$-statistik $\|<\| \mathrm{t}$-tabel $\|$

\begin{tabular}{|c|c|c|c|c|}
\hline Variable & Coefficient & Std. Error & t-Statistic & Prob. \\
\hline C & 0.434781 & 2.557109 & 0.170028 & 0.0085 \\
\hline CAR & 0.001342 & 0.000677 & 2.981967 & 0.0138 \\
\hline NIM & 0.014663 & 0.013281 & 3.104055 & 0.0056 \\
\hline LOG(LDR) & 0.035791 & 0.356777 & 4.456936 & 0.0276 \\
\hline LOG(BOPO) & -0.025751 & 0.016128 & -3.568267 & 0.0337 \\
\hline
\end{tabular}

Ho: ditolak bila $\| \mathrm{t}$-statistik $\|>\| \mathrm{t}$-tabel $\|$

Tabel 13

Uji t (Parsial)
Dengan melihat nilai estimasi pada t-tabel sebesar 1,98638 maka ditarik kesimpulan sebagai berikut:

1) Uji Hipotesis 1: Pengaruh Capital Adequacy Ratio (CAR) Terhadap Pertumbuhan Laba

Hol : Tidak Terdapat Pengaruh yang signifikan CAR terhadap pertumbuhan laba bank umum pemerintah.

Hal : Terdapat Pengaruh yang signifikan CAR terhadap pertumbuhan laba bank umum pemerintah

Dari hasil penelitian maka t-hitung dari variabel CAR secara parsial t-hitung $>\mathrm{t}$-tabel $(2.98197>1,98638)$ Nilai signifikansi sebesar $0,0138<0.05$ maka Hol ditolak dan Hal diterima. Sehingga dapat disimpulkan bahwa variabelCAR berpengaruh positif dan signifikan terhadap pertumbuhan laba. Hasil penelitian ini mendukung penelitian sebelumnya yang dilakukan oleh Nur Aini (2013), yang menemukan bahwa CAR berpengaruh positif dan signifikan terhadap pertumbuhan laba. Sehingga apabila CAR meningkat maka pertumbuhan laba akan meningkat.

2) Uji Hipotesis 2: Pengaruh Loan To Deposit Ratio (LDR) Terhadap Pertumbuhan Laba

Ho3 : Tidak Terdapat Pengaruh yang signifikan LDR terhadap pertumbuhan laba bank umum pemerintah.

Ha3 : Terdapat Pengaruh yang signifikan LDR terhadap pertumbuhan laba bank umum pemerintah

Uji pengaruh Loan to Deposit Ratio (LDR) secara parsial t-hitung > t-tabel $(4.4569>$ 1,98638) Nilai signifikansi sebesar $0.0276<$ 0.05 maka $\mathrm{Ho} 2$ ditolak dan $\mathrm{Ha} 2$ diterima. Sehingga dapat disimpulkan bahwa variabel LDR berpengaruh positif dan signifikan terhadap pertumbuhan laba. Hal ini sesuai dengan penelitian Yogi Prasanjaya, I Wayan Ramantha (2013) yang menemukan bahwa LDR berpengaruh positif terhadap pertumbuhan laba. Sehingga apabila terjadi kenaikan LDR maka pertumbuhan laba semakin meningkat. 
3) Uji Hipotesis 3: Pengaruh Net Interest Margin (NIM) Terhadap Pertumbuhan Laba

Ho2 : Tidak Terdapat Pengaruh yang signifikan NIM terhadap pertumbuhan laba bank umum pemerintah.

Ha2 : Terdapat Pengaruh yang signifikan NIM terhadap pertumbuhan laba bank umum pemerintah

Dari hasil penelitian ini Uji pengaruh NIM secara parsial t-hitung $>\mathrm{t}$-tabel $(3.104055>$ $1,98638)$ Nilai signifikansi sebesar 0,0056 $<0.05$ maka Ho3 ditolak dan Ha3 diterima Sehingga dapat disimpulkan bahwa variabel NIM berpengaruh positif terhadap pertumbuhan laba. Hal ini sesuai dengan penelitian Trie Widyastuti dan Mandagie (2010), yang menemukan bahwa NIM berpengaruh positif dan signifikan terhadap pertumbuhan laba. Sehingga apabila terjadi kenaikan NIM maka pertumbuhan laba semakin meningkat.

4) Uji Hipotesis 4: Pengaruh Biaya Operasional Terhadap Pendapatan Operasional (BOPO) Terhadap Pertumbuhan Laba

Ho4 : Tidak Terdapat Pengaruh yang signifikan NIM terhadap pertumbuhan laba bank umum pemerintah.

Ha4 : Terdapat Pengaruh yang signifikan NIM terhadap pertumbuhan laba bank umum pemerintah

Uji pengaruh $B O P O$ secara parsial sebesar ||-3.568267||

t-hitung $>$ t-tabel $(>1,98638)$ Nilai signifikansi sebesar $0.0337<0.05$ maka Ho4 ditolak dan Ha4 diterima. Sehingga dapat disimpulkan bahwa variabel BOPO berpengaruh negatif dan signifikan terhadap pertumbuhan laba. Hal ini sesuai dengan penelitian Teddy Rahman, SE (2009) yang menemukan bahwa BOPO berpengaruh negatif dan signifikan terhadap pertumbuhan laba. Sehingga apabila terjadi kenaikan BOPO maka pertumbuhan laba semakin menurun.

\section{c. Nilai Adjusted $R^{2}$}

Adjusted $R^{2}$ dapat didefinisikan sebagai proporsi atau presentase dari total variasi variabel dependen $\mathrm{Y}$ yang dijelaskan oleh garis regresi (variabel independen $\mathrm{X}$ ). Dengan demikian nilai koefisien determinasi ini terlatak antara 0 dan $1\left(0<R^{2}<1\right)$. Semakin mendekati angka 1 maka semakin baik garis regresi karena mampu menjelaskan data aktualnya. Semakin mendekati angka nol maka garis regresi kurang baik. Namun demikian, kita harus memahami bahwa rendahnya nilai $R^{2}$ dapat terjadi karena beberapa alasan. (Widarjono, 2011: 26-27).

Tabel 14

Uji Adjusted $R^{2}$

\begin{tabular}{llll} 
R-squared & 0.890078 & Mean dependent var & 2.423000 \\
Adjusted & & & \\
R-squared & 0.887763 & S.D. dependent var & 0.578963 \\
S.E. of & & Sum squared resid & 45.35257 \\
regression & 0.398954 & Sum \\
F-statistic & 11.67875 & Durbin-Watson stat & 0.957847 \\
$\begin{array}{l}\text { Prob(F- } \\
\text { statistic) }\end{array}$ & 0.000001 & & \\
\hline
\end{tabular}

Sumber: Data diolah (Eviews 7.0)

Nilai Adjusted R-square dari model didapat sebesar 0,887763 yang menunjukan bahwa kemampuan variabel independen (CAR, NIM, LDR, N,BOPO) dalam menjelaskan variabel dependen (pertumbuhan laba) adalah sebesar $88,78 \%$, sisanya sebesar $11,22 \%$ dijelaskan oleh variabel lain diluar model seperti infasi, BI rate dan lain-lain.

\section{Analisis Regresi Linier Berganda}

Penelitian ini menguji pengaruh CAR, NIM, LDR, BOPO terhadap 4 bank dengan pertumbuhan laba terbesar di Indonesia tahun 2010-2015. Model yang dipakai adalah Random Effect. Model ini mengestimasi data panel dimana variabel gangguan mungkin saling berhubungan antar waktu dan antar individu (Widarjono, 2011:235) Berikut hasil dari regresi panel dengan variabel dependen Pertumbuhan Laba: 
Tabel 15

Hasil Uji Analisis Regresi Linier Berganda

\begin{tabular}{|c|c|c|c|c|c|c|c|}
\hline Variable & Coefficient & & Std. Error & & t-Statistic & Prob. & \\
\hline C & 0.434781 & & 2.557109 & & 0.170028 & 0.0085 & \\
\hline CAR & 0.001342 & & 0.000677 & & 2.981967 & 0.0138 & \\
\hline NIM & 0.014663 & & 0.013281 & & 3.104055 & 0.0056 & \\
\hline LOG(LDR) & 0.035791 & & 0.356777 & & 4.456936 & 0.0276 & \\
\hline LOG(BOPO) & -0.025751 & & 0.016128 & & -3.568267 & 0.0337 & \\
\hline R-squared & & 0.890078 & & Mean dependent var & & & 2.423000 \\
\hline Adjusted R-squared & & 0.887763 & & S.D. dependent var & & & 0.578963 \\
\hline S.E. of regression & & 0.398954 & & Sum squared resid & & & 45.35257 \\
\hline F-statistic & & 11.67875 & & Durbin-Watson stat & & & 0.957847 \\
\hline Prob(F-statistic) & & 0.000001 & & & & & \\
\hline
\end{tabular}

Sumber : Data diolah(Eviews7.0)

$$
\begin{gathered}
\mathrm{Y}=0.4348+0.0013(\mathrm{CAR})+\quad 0.0358 \\
\ln (\mathrm{LDR})+0.0147(\mathrm{NIM})-0.0258 \ln (\mathrm{BOPO})+e
\end{gathered}
$$

t-hitung (0.170) (2.982) (3.104) (4.457)

$(-3.568)$

$$
\begin{aligned}
& R^{2}=0.890078 \\
& \text { F-hitung }=11,68 \\
& \mathrm{n}=96 \\
& \mathrm{df}=96-4-1=91
\end{aligned}
$$

Tingkat Signifikan pada level $\alpha=5 \%$ dimana $t$-tabel $(0,05: 91)=1,9863$

Berdasarkan persamaan regresi diatas, maka dapat diintepretasikan sebagai berikut :

a. Berdasarkan persamaan regresi linier berganda yang diperoleh besarnya konstanta pertumbuhan laba sebesar 0.4348 . Hal ini mengindikasikan bahwa ketika keempat variabel $\mathrm{x}=0$ maka pertumbuhan laba tetap memiliki nilai 0.4348. Hal ini berarti tingkat pertumbuhan laba terbentuk meski tidak ada faktor CAR, LDR, NIM dan BOPO. Besaran konstanta tersebut signifikan karena memiliki Prob t-hitung $=0.0085<0.05$ dan konstanta tersebut selain signifikan juga bernilai positif.

b. Besarnya koefisien regresi CAR (X1) sebesar positif 0,0013 dan berpengaruh signifikan karena memiliki Prob t-hitung $=0.0138<0.05$ Hal ini mengindikasikan bahwa apabila variabel independen $C A R$ terjadi peningkatan 1 point tanpa variabel lain maka akan menaikkan pertumbuhan laba sebesar 0,0013 kali dari nilai semula.

c. Besarnya koefisien regresi LOG LDR (X2) sebesar 0.0358 karena memiliki nilai Prob t-hitung $=0.0276<0.05$. Hal ini mengindikasikan bahwa apabila variabel independen Loan to Deposit Ratio naik sebesar 1 point tanpa variabel lain maka akan menaikkan pertumbuhan laba sebesar 0,0358

d. Besarnya koefisien regresi NIM (X3) sebesar positif 0,0147.karena memiliki nilai Prob t-hitung $=0.0056<0.05$. Hal ini mengindikasikan bahwa apabila variabel independen NIM terjadi peningkatan 1 point tanpa variabel lain maka akan menaikkan pertumbuhan laba sebesar 0,0147 .

e. Besarnya koefisien regresi LOG BOPO (X4) sebesar negatif -0.0258 karena memiliki nilai Prob t-hitung $=0.0337<0.05$. Hal ini mengindikasikan bahwa apabila variabel independen Loan to Deposit Ratio naik sebesar 1 point tanpa variabel lain maka akan menurunkan pertumbuhan laba sebesar 0.0258 .

\section{Pembahasan}

1. Pengaruh CAR terhadap pertumbuhan laba pada Perbankan Pemerintah

Kemampuan bank menyalurkan kredit 
terkendala dengan jumlah modal yang dimiliki. Semakin besar modal bank secara relatif yang diukur dengan CAR akan semakin besar kemampuan bank menyalurkan dana dalam bentuk kredit. Jika kredit yang diberikan memberikan pendapatan bunga yang lancar maka semakin banyak kredit yang diberikan akan semakin besar pertumbuhan laba. Pada Besarnya koefisien regresi CAR (X1) sebesar positif 0,0013 . Hal ini mengindikasikan bahwa apabila variabel independen $C A R$ naik sebesar 1 point maka akan menaikkan pertumbuhan laba sebesar 0,0013 Dari hasil penelitian diperoleh koefisien transformasi regresi untuk variabel CAR sebesar 0,0013 yang berarti berpengaruh secara positif terhadap pertumbuhan laba. Selain itu, nilai signifikasi yang dimiliki sebesar 0,0138 dimana nilai ini signifikan karena lebih kecil dari 0,05. Karena tingkat signifikansinya kurang dari 0,05 maka dalam hal ini pengaruh CAR terhadap pertumbuhan laba nyata. Dengan demikian hipotesis pertama yang menyatakan bahwa CAR berpengaruh positif terhadap pertumbuhan laba Bank Umum pemerintah diterima.

\section{Pengaruh LDR terhadap pertumbuhan laba pada Perbankan Pemerintah}

LDR adalah persentase jumlah dana pihak ketiga yang dapat disalurkan dalam bentuk pemberian kredit. Semakin besar LDR semakin besar pendapatan bunga kredit sehingga semakin besar pertumbuhan laba.

Berdasarkan persamaan regresi terlihat bahwa koefisien untuk variabel ini bernilai positif 0,03579 sehingga dapat diartikan bahwa pengaruh yang diberikan oleh variabel LDR terhadap pertumbuhan laba adalah positif. Koefisien regresi sebesar 0,03579 berarti setiap kenaikan LOG LDR(X2) sebesar 1 point akan menaikkan pertumbuhan laba sebesar 0,035791. menunjukkan nilai signifikansi sebesar 0,0276 yang artinya nilai signifikansinya dibawah 0,05. Hal ini berarti bahwa ada pengaruh variabel LDR secara signifikan terhadap pertumbuhan laba. Kondisi ini mengandung arti semakin tinggi nilai LDR mengakibatkan semakin tinggi tingkat pertumbuhan laba pada Bank Umum pemerintah.

\section{Pengaruh NIM terhadap pertumbuhan laba pada Perbankan Pemerintah \\ NIM adalah selisih pendapatan bunga dan} biaya bunga secara relatif terhadap jumlah aktiva produktif. Semakin besar NIM menunjukkan semakin besar pendapatan bunga diatas biaya bunga. Dengan demikian semakin besar NIM akan semakin besar pertumbuhan laba.

Besarnya koefisien regresi NIM(X3) sebesar positif 0,0147 . Hal ini mengindikasikan bahwa apabila variabel independen NIM naik sebesar 1\% maka akan menaikkan pertumbuhan laba sebesar 0,0147 . nilai signifikasi yang dimiliki sebesar 0,0056 dimana nilai ini signifikan karena lebih kecil dari 0,05. Karena tingkat signifikansinya kurang dari 0,05\% maka dalam hal ini pengaruh NIM terhadap pertumbuhan laba nyata.). NIM yang merupakan alat untuk mengukur kemampuan manajemen bank dalam mengelola aktiva produktifnya untuk menghasilkan pendapatan bunga bersih pendapatan bunga bersih tersebut diperoleh dari pendapatan bunga. Semakin besar rasio ini makin meningkatnya pendapatan bunga atas aktiva produktif yang dikelola bank. Demikian jika meningkatnya pendapatan maka akan meningkatkan tingkat Pertumbuhan Laba

\section{Pengaruh BOPO berpengaruh terhadap pertumbuhan laba pada}

Disamping biaya bunga bank juga mengeluarkan biaya operasional yang disebut biaya non bunga. Semakin kecil biaya operasional ini secara relatif terhadap pendapatan operasional maka akan semakin besar laba perusahaan termasuk pertumbuhan laba.

Besarnya koefisien regresi LOG $B O P O(\mathrm{X} 4)$ sebesar negatif $0,0258 \mathrm{Hal}$ ini mengindikasikan bahwa apabila variabel independen BOPO naik sebesar poin maka akan menurunkan 
pertumbuhan laba sebesar 0.0258 . Hal ini menunjukkan bahwa semakin tinggi nilai $\mathrm{BOPO}$ maka kegiatan operasional bank menjadi kurang efisien karena meningkatnya biaya operasional dan ini akan membuat pertumbuhan laba sebagai pengukur tingkat keuntungan bank juga akan mengalami penurunan. BOPO terhadap profitabilitas (pertumbuhan laba) menunjukkan nilai signifikansi sebesar 0,0337 yang artinya nilai signifikansinya dibawah 0,05 . Hal ini berarti bahwa ada pengaruh variabel BOPO secara negatif dan signifikan terhadap pertumbuhan laba. Hasil penelitian ini yaitu BOPO berpengaruh negatif signifikan terhadap pertumbuhan laba juga sesuai dengan penelitian yang dilakukan oleh Nur Aini (2013)

\section{Pengaruh CAR, NIM, LDR, BOPO secara simultan berpengaruh terhadap pertumbuhan laba pada perusahaan perbankan}

Berdasarkan uji F (simultan) CAR, NIM, LDR, BOPO secara bersama-sama (simultan) mempunyai pengaruh terhadap pertumbuhan laba. Hal ini ditunjukan dari hasil yang diperoleh melalui perbandingan F-hitung dan F-tabel yakni, F-hitung $>$ F-tabel $(11,67875>1.98638)$. Dengan nilai probabilitas F-statistik 0,0000001 yang lebih kecil dari tingkat signifikan (5\%) maka Ho ditolak dan Ha diterima. Dengan demikian, dapat disimpulkan bahwa variabel independen (CAR, NIM, LDR, BOPO) secara bersama-sama (simultan) berpengaruh positif dan signifikan terhadap pertumbuhan laba pada 4 bank umum pemerintah dengan pertumbuhan laba terbesar di Indonesia selama periode 2010-2015. Nilai Adjusted R-square dari model didapat sebesar 0,887763 yang menunjukkan bahwa kemampuan variabel independen (CAR, NIM, LDR, BOPO) dalam menjelaskan variabel dependen (pertumbuhan laba) adalah sebesar $88,78 \%$, sisanya sebesar $11,22 \%$ dijelaskan oleh variabel lain diluar model seperti infasi, BI rate dan lain-lain.

\section{KESIMPULAN DAN SARAN Kesimpulan}

Kesimpulan yang dapat diambil dari penelitian mengenai "Analisis Pengaruh Capital Adequacy Ratio (CAR), Loan To Deposit Ratio (LDR),Net Interest Margin (NIM), Operational Efficiency Ratio (BOPO) terhadap pertumbuhan laba pada Bank-Bank Umum Pemerintah Periode Tahun 2010-2015", adalah sebagai berikut:

1. Variabel CAR berpengaruh positif dan signifikan terhadap pertumbuhan laba pada Bank-Bank Umum Pemerintah Periode Tahun 2010-2015.

2. Variabel LDR berpengaruh positif dan signifikan terhadap pertumbuhan laba pada Bank-Bank Umum Pemerintah Periode Tahun 2010-2015.

3. Variabel NIM berpengaruh positif dan signifikan terhadap pertumbuhan laba pada Bank-Bank Umum Pemerintah Periode Tahun 2010-2015.

4. Variabel BOPO berpengaruh negatif dan signifikan terhadap pertumbuhan laba pada Bank-Bank Umum Pemerintah Periode Tahun 2010-2015.

5. VariabelCAR,LDR, NIM, dan BOPO secara bersama-sama (simultan) berpengaruh signifikan terhadap Pertumbuhan Laba Bank-Bank Umum Pemerintah Periode Tahun 2010-2015. Dengan Nilai Adjusted $R$-square dari model didapat sebesar 0,887763 yang menunjukan bahwa kemampuan variabel independen (CAR, NIM, LDR, BOPO) dalam menjelaskan variabel dependen (pertumbuhan laba) adalah sebesar $88,78 \%$, sisanya sebesar $11,22 \%$ dijelaskan oleh variabel lain diluar model seperti infasi, BI rate dan lain-lain.

\section{Saran}

Berdasarkan hasil penelitian yang telah dilakukan dapat berimplikasi terhadap pihakpihak yang terkait antara lain, sebagai berikut:

1. Dalam penelitian ini sampelnya adalah 
4 bank yang merupakan bank dengan peringkat 10 teratas, peneliti selanjutnya bisa saja menambahkan jumlah sampelnya agar hasil penelitian yang didapat lebih baik.

2. Dalam penelitian ini metode yang dipakai adalah regresi panel dan pengolahan datanya menggunakan software eviews 7 . Penelitian selanjutnya bisa menggunakan metode lain dan software yang lebih baru.

3. Saran terkait dari penelitian pertumbuhan laba bank umum pemerintah sangat memperhatikan NIM karena rasio ini sangat dominan dan signifikan yang harus ditingkatkan demi kelangsungan operasional bank yaitu dengan salah satu strategi yang ditempuh adalah memainkan suku bunga kredit dan suku bunga simpanan. Karena tidak bisa mengandalkan volume penyaluran kredit, maka bank menaikkan margin keuntungan. Caranya, dengan menurunkan bunga simpanan secepat mungkin dan menurunkan bunga kredit selambat mungkin dengan strategi ini bank meningkatkan profitabilitas nya.

4. Dari hasil penelitian CAR yang tinggi memiliki pengaruh positif dan signifikan sehingga harus diiringi strategi bisnis yang tepat yaitu mengekspansi kredit dengan efektif seperti cara "jemput bola" agar masyarakat dapat tersosialisasi dengan adanya penyaluran kredit . sehingga dengan strategi yang tepat bank tidak menanggung sendiri dana pihak ketiga yang semakin tinggi.

\section{DAFTAR PUSTAKA}

Juda, Agung, Bambang Kusmiarso. Erwin G. Hutapea. 2001. Andry Prasmuko dan Nugroho Joko Prastowo. "credit crunch di Indonesia: Fakta, Penyebab, dan Implikasi Kebijakan", direktorat Riset Ekonomi dan Kebijakan Moneter Bank Indonesia, Jakarta,

Halim, Alamsyah, dkk. "Banking Disinterme- diation and Its Implication for Monetery Policy : The Case of Indonesia". Buletin Ekonomi Moneter dan Perbankan, 2005.

Ali, Mashud. 2004. "Asset Liability Management: Menyiasati Risiko Pasar dan Risiko Operasional", Jakarta: PT. Gramedia.

Arthesa Ade, Handiman Edia. 2006. "Bank dan Lembaga Keuangan Bukan Bank”, PT. INDEKS Kelompok Gramedia.

Bambang Prasetyo, Miftahul Jannah. 2005. "Metode Penelitian kuantitatif Teori dan Aplikasi”, Jakarta PT.Raja Grafindo Persada.

Basar P, Adhly dan Ismady P, Ihsan. "Kondisi Perbankan 2011 dan Prospek 2010”, Economic Riview, Desember 2011.

Dendawijaya, Lukman. 2005. "Manejemen Perbankan". Jakarta: Ghaila Indonesia

Fahmi Irham dan Yovi Lavianti Hadi. 2010. "Pengantar Manajemen Pertumbuhan laba". Bandung: CV Alfabeta

Imam, Ghozali. 2011. "Aplikasi Analisis Multivariat dengan program IBM SPSS 19”. Semarang: UNDIP.

Damodar N, Gujarati. 2007. "Dasar-dasar Ekonometrika". Jakarta: Erlangga.

Mamduh, Hanafi, dan Halim, Abdul "Analisis Laporan Keuangan”, UPP AMP YKPN, Yogyakarta, 2005.

Sri, Haryati. "Pertumbuhan Laba Perbankan di Indonesia: Intermediasi dan pengaruh Variabel Makro Ekonomi". Jurnal Keuangan dan Perbankan Vol.13, No.2 Mei 2011.

Malayu, Hasibuan.2006. "Dasar-Dasar Perbankan". Cetakan Kelima. Jakarta: PT Bumi Aksara.

Hidayat Rustam dan Dwiatmanto. "Analisis Pengaruh Pertumbuhan Laba, CAR, NPL, dan LDR Terhadap Perkembangan Pertumbuhan Laba Perbankan". Fakultas Ilmu Administrasi. 2011.

Kasmir. 2010. "Manajemen Perbankan". Edisi Revisi 8. Jakarta: PT Raja Grafindo Persada. Manurung, Mandala, Prathama Rahardja.2004. "Uang, Perbankan, dan Ekonomi Moneter (Kajian Kontekstual Indonesia)". Jakarta: 
Penerbit FE UI.

Meydianawathi, Luh Gede. " Analisis Perilaku Penawaran PERTUMBUHAN LABA Perbankan Kepada Sektor UMKM di Indonesia". Buletin Studi Ekonomi Vol. 12 No. 2 tahun 2007.

Suharti, Gunarto. 2003. "Usaha Perbankan Dalam Perspektif Hukum". Yogyakarta. Kanisius.

Billy Arma, Pratama. "Analisis Faktor-faktor yang Mempengaruhi Kebijakan Pertumbuhan Laba Perbankan", Tesis UNDIP, 2010.

Ibnu, Purna, Hamidi, Prima." Pengaruh Krisis Keuangan Global Terhadap Sektor Finansial di Indonesia". Sekretariat Negara Republik Indonesia, 2011.

Slamet, Riyadi. 2006. "Banking Assets and Liability Manajement". Edisi ketiga, Fakultas Ekonomi Universitas Indonesia.

Dias ,Satria, dan Subegti Bagus. "Determinasi Pertumbuhan Laba Bank Umum di Indonesia periode 2006-2011". Jurnal Keuangan dan Perbankan, Vol. 14, No. 3 September 2010.

Scot, M.D \& Timothy W.K. 2006 "Manegement of Banking”. Thompson. South- Western.

Singgih, Santoso. 2000. "Buku Latihan SPSS Parametrik”. Jakarta: Elex Media Komputindo.

Suliyanto, 2011. "Ekonometrika Terapan Teori dan Aplikasi dengan SPSS", yogyakarta: ogyakarta: CV Andi Offset.

Triandaru Sigit, dan Totok Budisantoso. 2006. “Bank \& Lembaga Keuangan Lain”.Jakarta: Salemba Empat.

Warjiyo, Perry.2004. "Mekanisme Transmisi Kebijakan Moneter di Indonesia”, Jakarta: pusat pendidikan dan Studi kebanksentralan BI.

Widarjono, Agus.2011. "Ekonometrika pengantar dan aplikasinya". Yogyakarta: Ekonisia

Winarno, Wing Wahyu."Analisis Ekonometrika dan Statistika dengan Eviews"Sekolah tinggi ilmu manajemen YKPN. Yogyakarta.2011.
Enders, W. "Applied Econometric Time Series". John Wiley \& Sons, Inc.New York. 1995. www.bi.go.id www.lps.go.id www.idx.co.id www.jstor.org www.ojk.co.id www.mandiri.co.id www.bri.co.id www.bni. co.id www.btn.co.id 